Potravinarstvo Slovak Journal of Food Sciences vol. 13, 2019, no. 1, p. 884-890

https://doi.org/10.5219/1237

Received: 14 September 2019. Accepted: 21 November 2019. Available online: 28 November 2019 at www.potravinarstvo.com (C) 2019 Potravinarstvo Slovak Journal of Food Sciences, License: CC BY 3.0

ISSN 1337-0960 (online)

\title{
THE AMINO ACID PROFILE AFTER ADDITION OF HUMIC ACIDS AND PHYTOBIOTICS INTO DIET OF BROILER CHICKEN
}

\author{
Peter Haščik, Adriana Pavelková, Jana Tkáčová, Juraj Čuboň, Marek Bobko, \\ Miroslava Kačániová, Henrieta Arpášová, Matej Čech
}

\begin{abstract}
The aim of the study was analysed the effect of humic acids separately and humic acids in combination with phytobiotic as garlic and oregano powder on amino acid (AA) profile of the most valuable parts of Ross 308 chicken. A total of 200 pcs Ross 308 broiler chickens of mixed sex were randomly divided into 4 groups ( $\mathrm{n}=50$ ): control group (C) without supplementation, experiment group E1 (2\% humic acids), E2 (80\% humic acids and 20\% garlic powder) and E3 (90\% humic acids and $10 \%$ oregano powder). Fattening period lasted for 42 days and all groups were kept under the same conditions. After slaughter, the AA profiles of breast and thigh samples were determined. In comparison with control group, 6 out of 10 AA was significantly affected $(p \leq 0.05)$ by used dietary supplementation - Met, Cys and His in thigh and Leu, Phe, His and Arg in breast muscle. AA composition of breast muscle was positively affected mainly by humic acids and $10 \%$ oregano powder supplementation (E3), while thigh muscle by humic acids and $20 \%$ garlic powder (E2). The highest obtained AA in breast muscle was Leu (2.02 g. $\left.100 \mathrm{~g}^{-1}\right)$ in E3 group and thigh muscle His $\left(1.15 \mathrm{~g} .100 \mathrm{~g}^{-1}\right)$ in E2 group $(p \leq 0.05)$. In conclusion, humic acids and $10 \%$ oregano powder supplementation (E3) elicited to the best AA profile of chicken breast muscle but also the worst AA profile in thigh muscle so the effect of such a supplementation is disputable. On the other hand, humic acids and $20 \%$ garlic powder supplementation resulted into slight increase of AA in both breast and thigh muscle (E2).
\end{abstract}

Keywords: broiler chicken; amino acid; humic acid; garlic; oregano

\section{INTRODUCTION}

Meat and meat products are generally an important source of protein. Proteins are naturally occurring complex nitrogenous compounds and the percentage of the meat protein component varies considerably between different types of meat (Marangoni et al., 2015). Average protein content in chicken meat is about $20 \%$ and more than $40 \%$ of AAs are essential ones (Kim et al., 2017). Chicken meat offers all the EAAs and is characterized by a high content of lysine, leucine, aspartic acid and glutamic acid (Sales and Hayes 1996; Soriano-Santos 2010; Ramane et al., 2011).

Although commercial feed additive containing antibiotics can increase productivity, antibiotic residues in meats might have negative effects on human health when meats were consumed (Barton and Hart 2001; Khaksefidi and Rahimi, 2005). Thus, it needs alternative feed additives, which are safer, drug-free residue and to meet consumer demand. The possibility of using new natural materials including oregano, garlic and humic asids in diet of poultry is being researched (Haščík et al., 2017; Kalafova et al., 2018). Many natural substances have been shown to express positive effects on growth performance and different health parameters in animals (Hong et al., 2012; Thiamhirunsopit et al., 2014).

Many of plants and herbs can be used to improve the meat quality (Liu et al., 2008), because of development of antibiotic resistance and their banned in the European Union since 2006. In addition, they consider the other alternative feed supplements, replacing the use of antibiotics in chicken nutrition. Probiotics and bee products (Trembecká et al., 2017), organic acids, prebiotics, symbiotics, enzymes, organic minerals (Fulton et al., 2002) and plant essential oils (Cross et al., 2007) have been tested as suitable substitutes.

Plants and plant products, commonly referred to as phytobiotics, are natural, nontoxic, residue free, and readily available. Therefore, they are a suitable alternative to growth antibiotics. They have several effects on animals, such as appetite stimulation, increase digestive secretion, have immunostimulatory, bactericidal, antiviral and antioxidant effects (Hashemi and Davoodi, 2011; Giannenas et al., 2013). Specially the medicinal activities of some natural plants as garlic (Allium sativum L.), thyme 
(Thymus vulgaris), oregano (Origanum vulgare) and basil (Ocimum basilicum) are well known and documented (Kostadinović, 2013).

Humates, one of the potential substances alternative to antibiotics in the diet of poultry, are formed from decayed plant matter with the aid of living bacteria in the soil. Humates include humus, humic acid, fulvic acid, ulmic acid, and trace minerals. Humic acid is a natural organic acid and has been shown to influence digestion, immune response and general performance of broilers (Ozturk et al., 2012). The humic acids inclusion in broiler diets may stimulate changes in digestion dynamics, assimilation of nutrients and meat metabolite profiling, resulting in desirable meat compositional and organoleptic physiognomic quality (Ozbey and Esen, 2007).

In chicken and pork, humic acid inclusion in diets was observed to desirably modify meat colour mainly due to accelerated myoglobin synthesis (Wang et al., 2008; Ozturk et al., 2012). Moreover, in pork, humic acid was observed to have an effect of increasing the fat marbling values and to reduce back fat thickness, probably due its influence on protein and lipid distribution (Wang et al., 2008). From the results of Disetlhe et al. (2019), it can be concluded that the inclusion of enzymes and potassium humate in canola-based broiler diets had beneficial effects on the carcass and meat quality parameters in terms of breast weights, water holding capacity and colour.

Oregano (Origanum vulgare L.) is generaly an aromatic herb used to improve organoleptic characteristics of foods. Also it is a natural, less toxic, residue free feed supplement for poultry when compared to other synthetic ingredients. Its oil contains key bioactive components, including as thymol and carvacrol (Figiel et al., 2010; Alagawany, et al., 2018). These phenolic compounds have an antimicrobial, antioxidant, antiviral, immunomodulatory and antiparasitic effect. The potential advantages of utilising oregano extract, in poultry diets include improved feed intake and feed conversion, enhanced digestion, expanded productive performance, down-regulated disease incidence and economic losses (Arcila-Lozano et al., 2004; Fasseas et al., 2007) and reduce conventional antibiotics use (Symeon et al., 2010). From the available literature, average inclusions of oregano essential oil up to $600 \mathrm{mg} / \mathrm{kg}$ in broiler diets increased body weight gain. Using $1 \%$ oregano oil in broiler diets improved feed conversion ratio and feed utilisation (Alagawany, et al., 2018). But, chemical composition of oregano oil may vary due to weather, season of year, harvest cycle, process of extraction and crop location (Baydar et al., 2004; OrtegaNieblas et al., 2011).

Garlic (Allium sativum L.) is widely used in all parts of the world as a spice and herbal medicine for the prevention and treatment of a variety of diseases, ranging from infections to heart diseases (Javandel et al., 2008). Garlic is today use for a variety of reasons, it has anti-microbial, anti-bacterial, anti-inflammatory effects etc. (Mansoub, 2011). Garlic was reported as a natural feed additive, it has improved broiler chickens growth and feed conversion (Stanaćev et al., 2012). The major active ingredients in garlic are allicin, ajoene, diakyl polysulphides, s-allylcysteine etc which may be responsible for the various properties of garlic (Canogullari et al., 2010). Garlic has been found to lower serum, liver and tissue cholesterol (Stanaćev et al., 2012).
In broilers, it was reported that garlic as a natural feed additive, improved broiler growth and feed conversion ratio, and decreased mortality rate (Tollba and Hassan, 2003; Puvača et al., 2013). Suriya et al. (2012) suggested that inclusion of $0.5 \%$ garlic may have the potential to be an alternative to antibiotic growth promoter for broiler chicken.

The aim of the present study was analysed the effect of supplying humic acids separately and humic acids in combination with phytobiotic as garlic and oregano powder on amino acid (AA) profile of the most valuable carcass parts of Ross 308 chickens.

\section{Scientific hypothesis}

We are expecting the significant rise of AA content in breast and thigh muscle of broiler chicken after addition of humic acids, garlic and oregano into their diet.

\section{MATERIAL AND METHODOLOGY \\ Animals and experimental design}

The experiment was realized in the experimental poultry station of Slovak University of Agriculture (SUA) in Nitra. Chickens were randomized into four groups, each containing 50 birds. In control group we used complete feed mixture without any additives. Group of chickens E1 was fed a diet containing $2 \mathrm{~kg}$ of preparation Humac Natur per $100 \mathrm{~kg}$ feed mixture. The group marked as E2 was fed a diet containing $1.6 \mathrm{~kg}$ of preparation Humac Natur per $100 \mathrm{~kg}$ feed mixture and $0.4 \mathrm{~kg}$ of garlic powder per $100 \mathrm{~kg}$ feed mixture and group E3 containing combination $1.8 \mathrm{~kg}$ of preparation Humac Natur per $100 \mathrm{~kg}$ feed mixture and 0.2 $\mathrm{kg}$ of oregano leaf powder per $100 \mathrm{~kg}$ feed mixture. The experiment was realized by methology Haščík et al. (2018). Chickens in individual groups were stabled on deep budding, with a maximum occupation of the breeding areas $33 \mathrm{~kg} \cdot \mathrm{m}^{-2}$. During the fattening period, the light regimen based on $24 \mathrm{~h}$ of dark was used. The temperature at the beginning of the experiment was $31-33{ }^{\circ} \mathrm{C}$ and decreased to $20-22{ }^{\circ} \mathrm{C}$ during the experiment. The temperature was maintained using electronic hen-like devices providing radiant heat.

The fattening lasted 42 days. The feeding program included three phases: starter $\left(1^{\text {st }}-21^{\text {st }}\right.$ days of age $)$, grower $\left(22^{\text {nd }}-35^{\text {th }}\right.$ days of age $)$, and finisher $\left(36^{\text {th }}-42^{\text {nd }}\right.$ days of age). Feed and water were supplied ad libitum. The feed mixtures both starter and grower were produced without any antibiotics and coccidiostats. Composition of complete feed mixtures is presented in Table 1.

Humac Natur purchased from Humac s.r.o., Kosice is preparation of humic substances on base of oxihumolit contain min. $62 \%$ humic acids in dry matter, of this $48 \%$ free humic acids in dry matter, minerals and trace elements, carboxymethylcellulose complex with humic substances. Moisture was maximum 11\%.

The garlic was added to the feed in the form of finely ground Allium sativum L. bulbs and the oregano was added as dried and finely ground of Oreganum sativum leaves (Vetservis a.s.).

\section{Slaughter and measurements}

At the end of the 42-d feeding period, broilers were weighed and slaughtered at the slaughterhouse of Slovak University 
of Agriculture in Nitra. After evisceration, the carcasses were kept at approximately $18{ }^{\circ} \mathrm{C}$ for $1 \mathrm{~h}$ post mortem and thereafter carcasses were weighed and stored at $4{ }^{\circ} \mathrm{C}$ until $24 \mathrm{~h}$ post mortem. The breast and thigh muscles were separated from each half-carcass for the determination the AA composition. In breast and thigh muscles, measurements were made of the content of the EAAs (valine, leucine, isoleucine, phenylalanine, threonine, lysine, methionine) and NEAAs (histidine, arginine, cysteine) using an automatic amino acid analyzer AAA 400 (INGOS Prague, Czech Republic). This works on the principle of ionic exchange chromatography with postcolumn ninhydrin derivatization, based on procedure previously described by Moore and Stein (1963) approved by Bulletin of the Ministry of Agriculture and Rural Development of the Slovak Republic (MARD SR, 2004). Post-column ninhydrin derivatization has become the official standard in recent years. There has been some methodological advancement, but the technique is still used very widespread. Total amino acid content of meat was determined by acid hydrolysis of proteins. Sulphur amino acids are first oxidized to a stable oxidized derivative, and then acid hydrolysed. Tryptophan was not determined because of its decomposition during acid hydrolysis of proteins. The resultant values of amino acids were recalculated to $100 \%$ dry matter and expressed as g AA content per $100 \mathrm{~g}$ muscle.

Table 1 Composition of feed mixtures

\begin{tabular}{|c|c|c|c|}
\hline Ingredients (\%) & $\begin{array}{c}\text { Starter (HYD-01) } \\
\left(1^{\text {st }}-21^{\text {st }} \text { day of age }\right)\end{array}$ & $\begin{array}{c}\text { Grower (HYD-02) } \\
\left(22^{\text {nd }}-35^{\text {th }} \text { day of age }\right)\end{array}$ & $\begin{array}{c}\text { Finisher (HYD-03) } \\
\left(36^{\text {th }}-42^{\text {nd }} \text { day of age }\right)\end{array}$ \\
\hline Wheat & 34.50 & 34.50 & 36.32 \\
\hline Maize & 35.50 & 40.50 & 37.50 \\
\hline Soybean meal $(48 \%$ N) & 21.40 & 18.80 & 20.00 \\
\hline Fish meal $(71 \% \mathrm{~N})$ & 3.70 & 1.90 & - \\
\hline Dried blood & 1.25 & 1.25 & - \\
\hline Ground limestone & 1.00 & 1.05 & 1.10 \\
\hline Monocalcium phosphate & 1.00 & 0.70 & 1.00 \\
\hline Fodder salt & 0.10 & 0.15 & 0.20 \\
\hline Sodium bicarbonate & 0.15 & 0.20 & 0.25 \\
\hline Lysine & 0.05 & 0.07 & 0.29 \\
\hline Methionine & 0.15 & 0.22 & 0.29 \\
\hline Palm kernel oil Bergafat & 0.70 & 0.16 & 2.50 \\
\hline Premix Euromix BR 0.5\%" & 0.50 & 0.50 & 0.50 \\
\hline \multicolumn{4}{|l|}{ Nutrient composition $\left[\mathrm{g}^{\mathrm{kg}}{ }^{-1}\right]$} \\
\hline Linoleic acid & 13.52 & 14.20 & 14.92 \\
\hline Fibre & 30.17 & 29.92 & 30.53 \\
\hline Crude protein & 210.73 & 190.41 & 170.54 \\
\hline MEN (MJ.kg'-1) & 12.15 & 12.04 & 12.41 \\
\hline Ash & 24.22 & 19.92 & 38.47 \\
\hline Ca & 8.16 & 7.28 & 7.38 \\
\hline $\mathbf{P}$ & 6.77 & 5.71 & 6.01 \\
\hline $\mathbf{N a}$ & 1.68 & 1.75 & 1.74 \\
\hline
\end{tabular}

Note: *active substances per kilogram of premix: vitamin A 2500000 IU; vitamin E 20000 mg; vitamin D3 800 000 IU; niacin $12000 \mathrm{mg}$; d-pantothenic acid $3000 \mathrm{mg}$; riboflavin $1800 \mathrm{mg}$; pyridoxine $1200 \mathrm{mg}$; thiamine $600 \mathrm{mg}$; menadione $800 \mathrm{mg}$; ascorbic acid $20000 \mathrm{mg}$; folic acid $400 \mathrm{mg}$; biotin $40 \mathrm{mg}$; cobalamin $8.0 \mathrm{mg}$; choline $100000 \mathrm{mg}$; betaine 50000 mg; Mn 20000 mg; Zn 16000 mg; Fe 14000 mg; Cu 2400 mg; Co 80 mg; I 200 mg; Se 50 mg.

\section{Statistical analysis}

A statistical analysis was computed using the ANOVA procedures of SAS software with using of Enterprise Guide 4.2 application (version 9.3, SAS Institute Inc., USA, 2008). Data were reported as mean \pm standard deviation. Statistical significance was calculated using t-test. Differences between the groups were considered significant at $p \leq 0.05$.

\section{RESULTS AND DISCUSSION}

The results of experiment with Ross 308 broiler chickens after addition of humic acid, garlic and oregano into their diet, which was aimed at amino acid composition of breast and thigh muscle are presented into Table 2 and Table 3. The method used allowed measurement of 7 dispensable amino acids (EAA) and 3 indispensable amino acids (NEAA) in the muscles. The most abundant AAs (in decreasing order) in both breast and thigh muscles were Lys, followed by Leu, Arg, His, Thr and Phe.

Four AAs (Leu, Phe, His, Arg) in breast muscle were significantly affected $(p \leq 0.05)$ by dietary supplementation with humic acid (E1), combination of humic acid with garlic powder (E2) and combination of humic acid with oregano powder (E3) in comparison with control group (C). Their concentration in C group was Leu 1.94 g.100 gPhe $\quad 1.00 \quad$ g.100 g $\mathrm{g}^{-1}$, His 1.12 g.100 $\mathrm{g}^{-1}$ and Arg 1.56 g. $100 \mathrm{~g}^{-1}$. Among EAAs, the concentration of Leu, respectively Phe has sligthly increased $(p \leq 0.05)$ when chickens were fed with combination humic acid plus garlic powder (E2; 1.97 g. $100 \mathrm{~g}^{-1}$ resp. $1.02 \mathrm{~g} .100 \mathrm{~g}^{-1}$ ) and humic acid plus oregano leaf powder (E3; 2.02 g.100 g-1, resp. $\left.1.05 \mathrm{~g} .100 \mathrm{~g}^{-1}\right)$. 
Table 2 Effect of natural feed supplements on amino acid composition of chicken breast muscle

\begin{tabular}{|c|c|c|c|c|c|}
\hline $\begin{array}{l}\text { Parameter } \\
\text { Group }\end{array}$ & $\mathbf{C}$ & E1 & E2 & $\mathbf{E 3}$ & $p$-value \\
\hline \multicolumn{6}{|c|}{ EAA } \\
\hline Thr & $1.09 \pm 0.10$ & $1.02 \pm 0.12$ & $1.11 \pm 0.10$ & $1.13 \pm 0.08$ & 0.079 \\
\hline Val & $1.04 \pm 0.09$ & $0.98 \pm 0.08$ & $1.04 \pm 0.08$ & $1.08 \pm 0.06$ & 0.052 \\
\hline Met & $0.79 \pm 0.08$ & $0.74 \pm 0.08$ & $0.79 \pm 0.06$ & $0.82 \pm 0.06$ & 0.066 \\
\hline Ile & $0.95 \pm 0.12$ & $0.89 \pm 0.10$ & $0.97 \pm 0.09$ & $1.00 \pm 0.07$ & 0.051 \\
\hline Leu & $1.94 \pm 0.22^{\mathrm{ab}}$ & $1.81 \pm 0.20^{\mathrm{b}}$ & $1.97 \pm 0.16^{\mathrm{ab}}$ & $2.02 \pm 0.14^{\mathrm{a}}$ & 0.049 \\
\hline Phe & $1.00 \pm 0.11^{\mathrm{ab}}$ & $0.94 \pm 0.10^{\mathrm{b}}$ & $1.02 \pm 0.08^{\mathrm{ab}}$ & $1.05 \pm 0.07^{\mathrm{a}}$ & 0.045 \\
\hline Lys & $2.10 \pm 0.25$ & $1.95 \pm 0.22$ & $2.13 \pm 0.18$ & $2.19 \pm 0.15$ & 0.051 \\
\hline \multicolumn{6}{|c|}{ NEAA } \\
\hline Cys & $0.36 \pm 0.02$ & $0.33 \pm 0.04$ & $0.36 \pm 0.03$ & $0.36 \pm 0.02$ & 0.111 \\
\hline His & $1.12 \pm 0.14^{\mathrm{ab}}$ & $1.01 \pm 0.14^{\mathrm{b}}$ & $1.13 \pm 0.12^{\mathrm{ab}}$ & $1.19 \pm 0.09^{\mathrm{a}}$ & 0.029 \\
\hline Arg & $1.56 \pm 0.18^{\mathrm{ab}}$ & $1.45 \pm 0.16^{\mathrm{b}}$ & $1.58 \pm 0.13^{\mathrm{ab}}$ & $1.63 \pm 0.11^{\mathrm{a}}$ & 0.048 \\
\hline
\end{tabular}

Table 3 Effect of natural feed supplements on amino acid composition of chicken thigh muscle

\begin{tabular}{cccccc}
\hline $\begin{array}{c}\text { Parameter } \\
\text { Group }\end{array}$ & C & E1 & E2 & E3 & p-value \\
\hline \multicolumn{7}{c}{ EAA } \\
\hline Thr & $1.09 \pm 0.01$ & $1.08 \pm 0.04$ & $1.12 \pm 0.09$ & $1.05 \pm 0.08$ & 0.167 \\
Val & $1.04 \pm 0.01$ & $1.02 \pm 0.03$ & $1.04 \pm 0.08$ & $1.00 \pm 0.06$ & 0.173 \\
Met & $0.79 \pm 0.01^{\mathrm{b}}$ & $0.81 \pm 0.04^{\mathrm{ab}}$ & $0.87 \pm 0.05^{\mathrm{a}}$ & $0.78 \pm 0.05^{\mathrm{b}}$ & 0.011 \\
Ile & $0.97 \pm 0.01$ & $0.98 \pm 0.07$ & $1.02 \pm 0.07$ & $0.99 \pm 0.09$ & 0.138 \\
Leu & $1.97 \pm 0.02$ & $1.99 \pm 0.12$ & $2.07 \pm 0.15$ & $1.98 \pm 0.17$ & 0.175 \\
Phe & $1.01 \pm 0.01$ & $1.03 \pm 0.06$ & $1.07 \pm 0.08$ & $1.02 \pm 0.09$ & 0.166 \\
Lys & $2.13 \pm 0.02$ & $2.16 \pm 0.14$ & $2.26 \pm 0.17$ & $2.15 \pm 0.20$ & 0.107 \\
\hline Cys & $0.35 \pm 0.01^{\mathrm{b}}$ & $0.36 \pm 0.01^{\mathrm{b}}$ & $0.39 \pm 0.03^{\mathrm{a}}$ & $0.33 \pm 0.01^{\mathrm{c}}$ & 0.001 \\
His & $1.15 \pm 0.01^{\mathrm{a}}$ & $1.13 \pm 0.03^{\mathrm{a}}$ & $1.15 \pm 0.08^{\mathrm{a}}$ & $1.04 \pm 0.06^{\mathrm{b}}$ & 0.009 \\
Arg & $1.58 \pm 0.02^{\mathrm{N}}$ & $1.60 \pm 0.11$ & $1.67 \pm 0.12$ & $1.60 \pm 0.15$ & 0.127 \\
\hline
\end{tabular}

Notes: Amino acids are expressed on a dry matter basis (g. $\left.100 \mathrm{~g}^{-1}\right)$. Values are given as mean $\pm S D$ (standard deviation); $n=50 ; \mathrm{C}=$ control group; E1-E3 = experimental groups; ${ }^{\mathrm{a}-\mathrm{c}}=$ means within the same row with different superscripts differ significantly $(p \leq 0.05)$; EAA = essential amino acid; NEAA = non-essential amino acid; Thr = threonine; Val = valine; Met = methionine; Ile = isoleucine; Leu = leucine; Phe = phenylalanine; Lys = lysine; Cys = cysteine; His = histidine; Arg = arginine.

The content of mentioned AAs has decreased $(p \leq 0.05)$ after addition of humic acids (E1; $1.81 \mathrm{~g} .100 \mathrm{~g}^{-1}$, resp. 0.94 g. $100 \mathrm{~g}^{-1}$ ) in comparison with control group. Among NEAAs, amount of His, resp. Arg was positively affected $(p \leq 0.05)$ in E2 and E3 groups compared to $\mathrm{C}$ group. Their concentration was 1.12 g. $100 \mathrm{~g}^{-1}$, resp. $1.58 \mathrm{~g} .100 \mathrm{~g}^{-1}$ in E2 group and 1.19 g. $100 \mathrm{~g}^{-1}$, resp. $1.63 \mathrm{~g} .100 \mathrm{~g}^{-1}$.

Supplementation with humic acids alone led to slight decerase in His, resp. Arg to $1.01 \mathrm{~g} .100 \mathrm{~g}^{-1}$, resp.
1.45 g. $100 \mathrm{~g}^{-1}$. Other AAs in breast muscle were affected in the same way, but not significantly $(p \geq 0.05)$.

In thigh muscle, three AAs (Met, Cys, His) were significantly affected $(p \leq 0.05)$ by used dietary supplementations. Their concentration in $\mathrm{C}$ group was Met

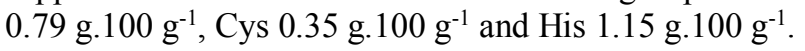

Among EAAs, the concentration of Met, respectively, has sligthly increased $(p \leq 0.05)$ when chickens were fed with combination humic acids (E1; 0.81 g. $100 \mathrm{~g}^{-1}$ ) and humic acid plus garlic powder (E2; $\left.0.87 \mathrm{~g} .100 \mathrm{~g}^{-1}\right)$. The content of Met has slightly decreased $(p \leq 0.05)$ after addition of humic 
acids (E3; 0.78 g.100 g $\mathrm{g}^{-1}$ ) in comparison with $\mathrm{C}$ group. Among NEAAs, amount of Cys was very gently increased $(p \leq 0.05)$ in E1 $\left(0.36 \mathrm{~g} .100 \mathrm{~g}^{-1}\right)$ and E2 $\left(0.39 \mathrm{~g} .100 \mathrm{~g}^{-1}\right)$ and decreased in E3 ( $\left.0.33 \mathrm{~g} .100 \mathrm{~g}^{-1}\right)$ groups compared to group C. On the other hand, Arg was not positively affected by any of used supplementation and was even decreased by humic acids plus oregano powder supplementation (E3; $\left.1.04 \mathrm{~g} .100 \mathrm{~g}^{-1}\right)$. As in the breast muscles, other AAs in thigh muscle were affected similarly, but not significantly $(p \geq 0.05)$.

The most abundant AAs (in decreasing order) in both breast and thigh muscles were Lys, followed by Leu, Arg, His, Thr and Phe. The lowest obtained AA was Cys in both breast and thigh muscle. Comparing breast with thigh muscle, the breast was found to contain higher amounts of all the EAAs and NEAAs detected in chicken meat, either the essential or the non-essential ones, which contrast with results reported by Chae et al. (2012), who observed higher AAs contents in chicken thigh compared with breast muscle. Similarly, higher values of AAs in chicken meat were found by Sharipova et al. (2017) except Lys and Tyr. According to Strakova et al. (2006) the general levels of individual amino acids in breast muscles of broiler chickens varied from 1.9 (Pro) to $11.0(\mathrm{Glu}) \mathrm{g} .100 \mathrm{~g}^{-1}$, while in thigh muscles ranged from 1.4 (Met) to 9.3 (Glu) g. $100 \mathrm{~g}^{-1}$. The total sum of amino acids in broiler chickens was 78.7 g. $100 \mathrm{~g}^{-1}$ in the breast muscles (essential AAs -

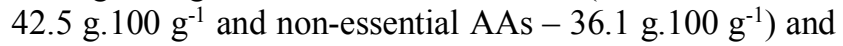

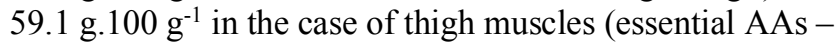
30.1 g. $100 \mathrm{~g}^{-1}$ and non-essential AAs - 29.2 g. $100 \mathrm{~g}^{-1}$ ).

When comparing between dietary groups, contents of most EAAs were the highest in experimental group E3 in breast muscle, with one expectation (Cys) and the lowest in E1 group. On the other hand, the breast muscle was affected different by our supplementation - E3 had the lowest AA content and the best affected group was E2.

Amino acids are generally seen as main precursors of flavour substances. In particular, Glu was shown to have considerable effect on taste of chicken meat. In addition to Glu, free aromatic AAs, such as Phe and Tyr, also play an important role in enhancing the savoury or umami taste at sub-threshold concentrations in the presence of salt and free acidic AAs (Wattanachant et al., 2004; Huang et al., 2011). Other AAs, such as Cys, Gly, Asp, Arg, and Ala, are also considered the flavour-related AAs (Liu et al., 2008). Independently from these results, it is important to emphasize the way of heat treatment to AA composition. From the results of Shehab (2016) it is clear that any heat treatment of fresh thighs or breasts causes some reduction in all amino acids. Samples from chicken breasts and thighs cooked under pressure retained the highest percentage of total, essential and non-essential amino acids. Methods such as ordinary cooking, oven and frying followed. In particular, their loss in juice separated during cooking as well as thermal decomposition may be responsible for the reduction of the amino acid content.

\section{CONCLUSION}

The addition of garlic and oregano powder in combination with humic acids can affect the AA profile of chicken meat. In breast muscle, supplementation with humic acids plus garlic povder and also oregano increased content of all AA. Unfortunately, humic acids alone decreased AA content in experimental groups compared to the control group. The AA content of the thigh muscle was increased only after the addition of the humic acids with garlic powder compared to the control. The effects of the tested supplements may positively influence AA content; however, we recommend further review to verify their effectiveness.

\section{REFERENCES}

Arcila-Lozano, C. C., Loarca-Piña, G., Lecona-Uribe, S., González de Mejía, E. 2004. El orégano: propiedades, composición y actividad biológica de sus componentes. Archivos Latinoamericanos de Nutrición, vol. 54, no. 1, p. 100111.

Barton, M. D., Hart, W. S. 2001. Public health risks: Antibiotic resistance- A review. Asian-Australasian Journal of Animal Sciences, vol. 14, no. 3, p. 414-422. https://doi.org/10.5713/ajas.2001.414

Baydar, H., Sağdiç, O., Özkan, G., Karadoğan, T. 2004. Antibacterial activity and composition of essential oils from Origanum, Thymbra and Satureja species with commercial importance in turkey. Food Control, vol. 15, no. 3, p. 169-172. https://doi.org/10.1016/S0956-7135(03)00028-8

MARD SR, 2004. Bulletin of MARD SR (Ministry of Agriculture and Rural Development of the Slovak Republic). Decree of Ministry of Agriculture and Rural Development of the Slovak Republic No. 2145/2004-100 of 23 August 2004 changing and amending Decree of Ministry of Agriculture and Rural Development of the Slovak Republic No. 1497/1/1997100 of 7 October 1997 regulating laboratory testing and feed assessment as amended by Decree of Ministry of Agriculture and Rural Development of the Slovak Republic No. 149/2/2003-100 of 12 February 2003.

Canogullari, S., Baylan, M., Erdogan, Z., Duzguner, V., Kucukgul, A. 2010. The effect of dietary garlic powder on performance, egg yolk and serum cholesterol concentration in laying quails. Czech Journal of Animal Science, vol. 55, no. 7, p. 286-293. https://doi.org/10.17221/126/2009-cjas

Cross, D. E,, McDevitt, R. M., Hillman, K., Acamovic, T. 2007. The effect of herbs and their associated essential oils on performance, dietary digestibility and gut microflora in chickens from 7 to 28 days of age. British Poultry Science, vol. 48, no. 4, p. 496-506.

https://doi.org/10.1080/00071660701463221

Disetlhe, A. R. P., Marume, U., Mlambo, V., Hugo, A. 2019. Effects of dietary humic acid and enzymes on meat quality and fatty acid profiles of broiler chickens fed canola-based diets. Asian-Australasian Journal of Animal Sciences, vol. 32, no. 5, p. 711-720. https://doi.org/10.5713/ajas. 18.0408

Fasseas, M. K, Mountzouris, K. C., Tarantilis, P. A., Polissiou, M., Zervas, G. 2007. Antioxidant activity in meat treated with oregano and sage essential oils. Food Chemistry, vol. 106, no. 3, p. 1188-1194. https://doi.org/10.1016/j.foodchem.2007.07.060

Figiel, A., Szumny, A., Gutiérrez-Ortiz, A., CarbonellBarrachina, A. A. 2010. Composition of oregano essential oil (Origanum vulgare) as affected by drying method. Journal of Food Engineering, vol. 98, no. 2, p. 240-247. https://doi.org/10.1016/j.jfoodeng.2010.01.002

Fulton, R. M., Nersessian, B. N., Reed, W. M. 2002. Prevention of Salmonella enteritidis infection in commercial ducklings by oral chicken egg-derived antibody alone or in combination with probiotics. Poultry Science, vol. 81, no. 1, p. 34-40. https://doi.org/10.1093/ps/81.1.34

Giannenas, I., Bonos, E., Christaki, E., Florou-Paneri, P. 2013. Essential oils and their applications in animal nutrition. 
Medicinal \& Aromatic Plants, vol. 2, no. 6, p. 1-12. https://doi.org/10.1155/2016/5436738

Hashemi, S. R., Davoodi, H. 2011. Herbal plants and their derivatives as growth and health promoters in animal nutrition. Veterinary Research Communication, vol. 35, no. 3, p. 169180. https://doi.org/10.1007/s11259-010-9458-2

Haščík, P., Pavelková, A., Bobko, M., Trembecká, L., Elimam, I. O. E., Capcarova, M. 2017. The effect of bee pollen in chicken diet. World's Poultry Science Journal, vol. 73, no. 3, p. 643-650. https://doi.org/10.1017/s0043933917000435

Haščík, P., Trembecká, L., Bobko, M., Čuboň, J., Kačániová, M., Tkáčová, J. 2018. Amino acid profile of broiler chickens meat fed diets supplemented with bee pollen and propolis. Journal of Apicultural Research, vol. 55. no. 4, p. 324-334. https://doi.org/10.1080/00218839.2016.1245398

Hong, J., Steiner, T., Aufy, A., Lien, T. 2012. Effects of supplemental essential oil on growth performance, lipid metabolites and immunity, intestinal characteristics, microbiota and carcass traits in broilers. Livestock Science, vol. 144, no. $3, \quad$ p. 253-262. https://doi.org/10.1016/j.livsci.2011.12.008

Huang, A., Li, J., Shen, J., Tao, Z., Ren, J., Li, G., Wang, D., Tian, Y., Yang, F., Ding, W., Wu, T., Lu, L. 2011. Effects of crossbreeding on slaughter traits and breast muscle chemical composition in chinese chickens. Revista Brasileira de Ciência Avícola, vol. 13, no. 4, p. 247-253. https://doi.org/10.1590/s1516-635x2011000400005

Chae, H. S., Choi, H. C., Na, J. C., Kim, M. J., Kang, H. K., Kim, D. W., Kim, J. H., Jo, S. H., Kang, G. H., Seo, O. S. 2012. Effect of Raising Periods on Amino Acids and Fatty Acids Properties of Chicken Meat. Korean Journal of Poultry Science, vol. 39, no. 2, p. 77-85. https://doi.org/10.5536/kjps.2012.39.2.077

Javandel, F., Navidshad, B., Seifdavati, J., Pourrahi, G. H., Baniyaghoub, S. 2008. The favorite dosage of garlic meal as a feed additive in broiler chickens ratios. Pakistan Journal of Biolgy Sciences, vol. 11, no. 13, p.1746-1749. https://doi.org/10.3923/pjbs.2008.1746.1749

Kalafova, A., Hrncar, C., Zbynovska, K., Bucko, O., Hanusova, E., Kapustova, Z., Schneidgenova, M., Bielik, P., Capcarova, M. 2018. The effects of dietary probiotics and humic acid on meat quality of Japanese quail including sexrelated differences and economical background. Biologia, vol. 73, no. 8, p. 765-771. https://doi.org/10.2478/s11756-0180085-7

Khaksefidi, A., Rahimi, Sh. 2005. Effect of probiotic inclusion in the diet of broiler chickens on performance, feed efficiency and carcass quality. Asian-Australasian Journal of Animal Sciences, vol. 18, no. 8, p. 1153-1156. https://doi.org/10.5713/ajas.2005.1153

Kim, H., Do, H., Chung, H. 2017. A Comparison of the Essential Amino Acid Content and the Retention Rate by Chicken Part according to Different Cooking Methods. Korean Journal for Food Science of Animal Resources, vol. 37, no. 5, p. 626-634. https://doi.org/10.5851/kosfa.2017.37.5.626

Kostadinović, L. 2013. Uticaj lekovitog bilja na zdravlje životinja. Monografija. Univerzitet u Novom Sadu, Institut za prehrambene tehnologije, Novi Sad, Srbija. 86 p. ISBN 97886-7994-036-0

Liu, H., Qiu, N., Ding, H., Yao, R. 2008. Polyphenols contents and antioxidant capacity of 68 Chinese herbals suitable for medical or food uses. Food Research International, vol. 41, no. 4, p. 363-370. https://doi.org/10.1016/j.foodres.2007.12.012
Mansoub, N. H. 2011. Comparative Effects of Using Garlic as Probiotic on Performance and Serum Composition of Broiler Chickens. Annals of Biological Research, vol. 2, no. 3, p. 486- 490 .

Marangoni, F., Corsello, G., Cricelli, C., Ferrara, N., Ghiselli, A., Lucchin, L., Poli, A. 2015. Role of poultry meat in a balanced diet aimed at maintaining health and wellbeing: An Italian consensus document. Food and Nutrition Research, vol. 59, no. $1, \quad$ p. 27606. https://doi.org/10.3402/fnr.v59.27606

Ortega-Nieblas, M. M., Robles-Burgueño, M. R., AcedoFélix, E., González-León, A., Morales-Trejo, A., VázquezMoreno, L. 2011. Chemical composition and antimicrobial activity of oregano (Lippia palmeri S. WATS) essential oil. Revista Fitotecnia Mexicana, vol. 34, no. 1, p. 11-17.

Ozbey, O., Esen, F. 2007. The effects of breeding systems and stocking density on some blood parameters of rock partridges (Alectoris graeca). Poultry Science, vol. 86, no. 2, p. 420-422. https://doi.org/10.1093/ps/86.2.420

Ozturk, E., Ocak, N., Turan, A., Erener, G., Altop, A, Cankaya, S. 2012. Performance, carcass, gastrointestinal tract and meat quality traits, and selected blood parameters of broilers fed diets supplemented with humic substances. Journal of the Science of Food and Agriculture, vol. 92, no. 1, p. 59-65. https://doi.org/10.1002/jsfa.4541

Puvača, N., Stanaćev, V., Glamočić, D., Lević, J., Perić, L., Stanaćev, V., Milić, D. 2013. Beneficial effects of phytoadditives in broiler nutrition. World's Poultry Science Journal, vol. 69, no. 1, p. 27-34. https://doi.org/10.1017/S0043933913000032

Ramane, K., Galoburda, R., Kreicbergs, V., Vanaga, I. 2011. Amino acid profile of sous vide cooks poultry breast meat products. In 11 th International Congress on Engineering and Food (ICEF11) Proceedings "Food Process Engineering in a Changing World", Athens, Greece.

Sales, J., Hayes, J. P. 1996. Proximate, amino acid and mineral composition of ostrich meat. Food Chemistry, vol. 56, no. 2 , p. 167-170. https://doi.org/10.1016/03088146(95)00201-4

SAS 2008. 9.3 Enhanced Logging Facilities (Computer software). Cary, NC : SAS Institute Inc.

Sharipova, A., Khaziev, D., Kanareikina, S., Kanareikin, V., Rebezov, M., Kazanina, M., Andreeva, A., Okuskhanova, E., Yessimbekov, Z., Bykova, O. 2017. The Effects of a Probiotic Dietary Supplementation on the Amino Acid and Mineral Composition of Broilers Meat. Annual Research \& Review in Biology, vol. 21, no. 6, p. $1-7$. https://doi.org/10.9734/arrb/2017/38429

Soriano-Santos, J. 2010. Chemical Composition and Nutritional Content of Raw Poultry Meat. In GuerreroLegarreta, I. 2010. Handbook of Poultry Science and Technology, Volume 1, Primary Processing. Hoboken : John Wiley \& Sons. p. 467-491. ISBN 978-0-470-18552-0. https://doi.org/10.1002/9780470504451.ch25

Stanaćev, V., Glamočić, D., Milošević, N., Perić, L., Puvača, N., Stanaćev, V., Milić, D., Plavša, N. 2012. Influence of garlic (Allium sativum L.) and copper as phytoadditives in the feed on the content of cholesterol in tissues of the chickens. Journal of Medicinal Plants Research, vol. 6, no. 14, p. 2816-2819 https://doi.org/10.1017/S0043933915002214

Strakova, E., Suchy, P., Vitula, F., Vecerek, V. 2006. Differences in the amino acid composition of muscles from pheasant and broiler chickens. Archiv fur Tierzucht, vol. 49, no. 5, p. 508-514. https://doi.org/10.5194/aab-49-508-2006

Suriya, R., Zulkifli, I., Alimon, A. R. 2012. The effect of dietary inclusion of herbs as growth promoter in broiler 
chickens. Journal of Animal and Veterinary Advances, vol. 11, no. 3, p. 346-50. https://doi.org/10.3923/javaa.2012.346.350 Symeon, G. K., Zintilas, C., Demiris, N., Bizelis, L. A., Deligeorgis, S. G. 2010 Effects of oregano essential oil dietary supplementation on the feeding and drinking behaviour as well as the activity of broilers. International Journal of Poultry Science, vol. 9, no. 4, p. 401-405 https://doi.org/10.3923/ijps.2010.401.405

Shehab, T. 2016. Effect of cooking methods on amino acids composition of chicken meat. Theory and practise of meat processing, vol. 1, no. 4, p. 11-18. https://doi.org/10.21323/2414-438X-2016-1-4-11-18

Alagawany, M., Abd El-Hack, M. E., Farag, M. R., Shaheen, H. M., Abdel-Latif, M. A., Noreldin, A. E., Patra, A. K. 2018. The usefulness of oregano and its derivatives in poultry nutrition. World's Poultry Science Journal, vol. 74, no. 3, p. 463-473. https://doi.org/10.1017/S0043933918000454

Thiamhirunsopit, K., Phisalaphong, C., Boonkird, S., Kijparkorn, S. 2014. Effect of chili meal (Capsicum frutescens LINN.) on growth performance, stress index, lipid peroxidation and ileal nutrient digestibility in broilers reared under high stocking density condition. Animal Feed Science and Technology, vol. 192, p. 90-100. https://doi.org/10.1016/j.anifeedsci.2014.03.009

Tollba, A. A. H., Hassan, M. S. H. 2003. Using some natural additives to improve physiological and productive performance of broiler chicks under high temperature conditions. Black cumin (Nigella sativa) or Garlic (Allium sativum). Egyptian Poultry Science Journal, vol. 23, no. 2, p. 327-340.

Trembecká, L., Haščík, P., Čuboň, J., Bobko, M., Cviková, P., Hleba, L. 2017. Chemical and sensory characteristics of chicken breast meat after dietary supplementation with probiotic given in combination with bee pollen and propolis. Journal of microbiology, biotechnology and food sciences, vol. 7, no. 3, p. https://doi.org/10.15414/jmbfs.2017/18.7.3.275-280

Wang, Q., Chen, Y. J., Yoo, J. S., Kim, H. J., Cho, J. H., Kim, I. H. 2008. Effects of supplemental humic substances on growth performance, blood characteristics and meat quality in finishing pigs. Livestock Science, vol. 117, no. 2-3, p. 270-274. https://doi.org/10.1016/j.livsci.2007.12.024

Wattanachant, S., Benjakul, S., Ledward, D. 2004. Composition, Color, and Texture of Thai Indigenous and Broiler Chicken Muscles. Poultry Science, vol. 83, no. 1, p. 123-128. https://doi.org/10.1093/ps/83.1.123

\section{Acknowledgments:}

This work was supported by grant KEGA 013SPU-4/2018 and VEGA 19-002-00.
Contact address:

*Peter Haščík, Slovak University of Agriculture, Faculty of Biotechnology and Food Sciences, Department of Technology and Quality of Animal Products, Tr. A. Hlinku 2, 94976 Nitra, Slovakia, Tel.: +421376414708,

E-mail: peter.hacsik@uniag.sk

ORCID: https://orcid.org/0000-0002-3402-5658

Adriana Pavelková, Slovak University of Agriculture, Faculty of Biotechnology and Food Sciences, Department of Technology and Quality of Animal Products, Tr. A. Hlinku 2, 94976 Nitra, Slovakia, Tel.: +421376414313,

E-mail: adriana.pavelkova@uniag.sk

ORCID: https://orcid.org/0000-0002-8275-8557

Jana Tkáčová, Slovak University of Agriculture, Faculty of Biotechnology and Food Sciences, Department of Technology and Quality of Animal Products, Tr. A. Hlinku 2, 94976 Nitra, Slovakia, Tel.: +421376414428,

E-mail: jana.tkacova@uniag.sk

ORCID: https://orcid.org/0000-0002-8236-2536

Juraj Čuboň, Slovak University of Agriculture, Faculty of Biotechnology and Food Sciences, Department of Technology and Quality of Animal Products, Tr. A. Hlinku 2, 94976 Nitra, Slovakia, Tel.: +421376414709,

E-mail: juraj.cubon@uniag.sk

ORCID: https://orcid.org/0000-0002-1388-1527

Marek Bobko, Slovak University of Agriculture, Faculty of Biotechnology and Food Sciences, Department of Technology and Quality of Animal Products, Tr. A. Hlinku 2, 94976 Nitra, Slovakia, Tel.: +421376414113,

E-mail: marek.bobko@uniag.sk

ORCID: https://orcid.org/0000-0003-4699-2087

Miroslava Kačániová, Slovak University of Agriculture, Faculty of Horticulture and Landscape Engineering, Department of Fruit Science, Viticulture and Enology, Tr. A. Hlinku 2, 94976 Nitra, Slovakia, Tel.: +421376414715, E-mail: miroslava.kacaniova@gmail.com

ORCID: https://orcid.org/0000-0003-1336-4594

Henrieta Arpášová, Slovak University of Agriculture, Faculty of Agrobiology and Food Resources, Department of Small Animal Science, Tr. A. Hlinku 2, 94976 Nitra, Slovakia, Tel.: ++42137641 4314,

E-mail: henrieta.arpasova@uniag.sk

ORCID: https://orcid.org/0000-0001-8098-8044

Matej Cech, Slovak University of Agriculture, Faculty of Biotechnology and Food Sciences, Department of Technology and Quality of Animal Products, Tr. A. Hlinku 2, 94976 Nitra, Slovakia, Tel.: +421376414309,

E-mail: xcech@is.uniag.sk

Corresponding author: * 